Received: 06/06/2018

Revision: 18/10/2018

Accepted: 23/09/2018

OnlineFirst: 13/12/2018

\title{
Pedagogical Utility of Pre-Listening Activities for Improving Iranian Elementary EFL Learners' Listening Comprehension
}

\section{Fatemeh Karimi}

Ph.D. candidate, Isfahan (Khorasgan) Branch, Islamic Azad University of Isfahan, Isfahan, Iran, fatinaz.karimi@yahoo.com

\section{Azizeh Chalak}

Assoc. Prof., Isfahan (Khorasgan) Branch, Islamic Azad University of Isfahan, Isfahan, Iran,azizeh_chalak@yahoo.com

\section{Reza Biria}

Assoc. Prof., Isfahan (Khorasgan) Branch, Islamic Azad University of Isfahan, Isfahan, Iran,r_biria@yahoo.com

This study examined the effects of two types of pre-listening activities: bottom-up and top-down on Iranian elementary EFL learners' listening comprehension performance. By TOFEL (PBT) test, 90 learners were selected as elementary ones for this study. They were randomly assigned to two experimental and one control groups each consisting of 30 learners. After giving the pretest, vocabulary preparation and content related support were given as the treatment to two experimental groups. The learners in control group received filler activities. At the end of the experiment, the posttest was performed to all learners to measure the possible effects of the treatment. The results revealed the significant differences between the learners' pre-test and post test scores. The analyses of the data confirmed the great impact of pre-listening support on listening comprehension performance of Iranian elementary EFL learners.

Keywords: bottom-up, top-down, pre-listening, content related support, vocabulary preparation

\section{INTRODUCTION}

Listening is the most widely used language skill. Language learning depends on listening. Listening provides the aural input that is the basis for language acquisition (Krashen, 1985, 1996; Rost, 1990; Vandergrift, 1999). Rost (2002, p.10) points out that "since listening is the main channel of L2 acquisition, the development of listening should receive great importance in instruction". In EFL contexts, language learners have

Citation: Karimi, F., Chalak, A., \& Biria, R. (2019). Pedagogical Utility of Pre-Listening Activities for Improving Iranian Elementary EFL Learners' Listening Comprehension. International Journal of Instruction, 12(1), 1127-1140. https://doi.org/10.29333/iji.2019.12172a 
more difficulty understanding spoken language than written one (Chang \& Read, 2006). This fact is not surprising because of the complexity of the listening process using linguistic and non-linguistic sources to interpret the incoming data (Buck, 2001).

In many countries that English is used as a foreign language, educational settings and classrooms have found special importance because they are the only places that the learners are exposed to the foreign language. According to Underwood (1989), given the lack of less exposure to the spoken language in EFL contexts, such learners need to be tuned in rather than being plunged straight into listening tasks without any preparation. However, it is often seen that listening practice is given minimal class time. This situation affects EFL students and results in low listening comprehension achievement. EFL learners need extra support for better listening comprehension performance. A potential remedy to the above drawback can be the application of different types of prelistening which render listening classes more enjoyable and immerse learners in listening.

Pre-listening is the stage of preparation and warming up of the whole process of listening. It is a kind of "preparatory work" (Underwood, 1989; p.31) which enables the learners to deal with the following listening text strategically. Pre-listening activity, therefore, is very important in order to help students for better performance on L2 listening comprehension.

All pre-listening activities can be generally categorized into two types: bottom-up and top-down. While there are many bottom-up and top-down activities, the present study tried to shed light on the effects of vocabulary preparation as bottom-up pre-listening and content related support as top-down pre-listening activities on listening comprehension performance of Iranian elementary EFL learners. The present study took into consideration the shortcomings of EFL classes and tried to determine the extent to which vocabulary preparation and content related support can help EFL learners' listening comprehension performance.

The implementation of pre-listening activities has been the subject of an increasing number of studies. Their results do not seem to be congruent. Some studies indicated that providing content related support facilitated listening comprehension process (Schmidt-Rinehart, 1994; Sadeghi \& Zare, 2002). In contrast, some studies reported that schema activation in the form of content related support did not improve listening comprehension performance (Chiang \& Dunkel, 1992; Jensen and Hansen, 1995). With regards to the studies relating to the role of vocabulary preparation as a pre-listening, there exist different results. While some studies confirmed its usefulness (Pan, 2012; Farrokhi \& Modarres, 2012), others doubted its values (Chang \& Read, 2006; Chung, 2002).

It is, therefore, important to investigate the effects of these two types of pre-listening activities to remove the limitations of previous studies and reach to a solid conclusion. To meet this aim, this study tried to see whether there is any significant difference between the effects of two types of pre-listening activities, vocabulary preparation and content related support, on the performance of Iranian elementary EFL learners? 
The theoretical base of this study was schema theory. Bartlett (1932, p.201) defines schema as "an active organization of past reactions or experiences". This theory claims that "in comprehending language, people activate relevant schemata allowing them to process and interpret new experiences quickly and efficiently" (Richards \& Schmidt, 2010, p.510). According to this theory "comprehending of a text is an interactive process between the reader's background knowledge and the text" (An, 2013; p.130).

Fang (2008) points out that listening comprehension is an active process of constructing meaning that listener focuses on the selected pieces of aural input, and relates what they heard to his/her existing knowledge. Therefore, activation of appropriate schemata during the message processing will be essential for efficient comprehension (Carrell $\&$ Eisterhold, 1983). This theory was excessively influential for directing this research.

Different kinds of schemata were suggested by Urquhart and Weir (1998, p.71): which are as "formal schemata, content schemata, and cultural schemata". A linguistic schema was also added by Caroll (1983). This research is concerned with content schema and linguistic schema. Carrel and Eisterhold (1983, P.79) define the content schema as "background knowledge of the content area of the text" and linguistic schema as "knowledge about grammar and vocabulary". Linguistic schema refers to the existing knowledge of the listener and plays a basic role in comprehension. According to Eskey (1988) successful comprehension depends on the activation of both linguistic schema and content schema. Pre-listening activities, conducted before actual listening, activate the appropriate schemata and hence, facilitate the learners' listening comprehension.

The method employed to investigate the efficiency of vocabulary preparation and content related support pre-listening activities was the pretest posttest equivalent group design. By employing quantitative research methodology, this study examined how various pre-listening activities affect listening comprehension performance of the learners.

\section{THE REVIEW OF LITERATURE}

The effect of pre-listening activities on listening comprehension performance has been the subject of an increasing number of studies. Many studies investigated the effectiveness of the top-down pre-listening activities on listening comprehension performance of the EFL learners by activating the pre-existing knowledge of the learners.

Herron (1994), for example, examined the efficiency of advance organizer strategy as a top-down pre- listening activity. An advance organizer is providing relevant background information before listening to the passage. It will improve comprehension by limiting the number of possible interpretations of the passage. Data analysis showed the significant difference between two groups. The comparison of mean scores revealed that the comprehension of the students in treatment group was increased by the advance organizer strategy as pre-activity. Schmidt-Rinehart (1994) could also show that topic familiarity had a great impact on learners' listening comprehension. Jia (2010) also investigated the effect of schema activation through providing the related background 
knowledge. The results revealed that activating the relevant background knowledge helped learners to recognize more words and minimize the probability of miscomprehension. The significant role of the relevant prior knowledge on listening performance of EFL learners was also approved by Sadeghi and Zare (2002). They studied the impact of background knowledge on learners' listening comprehension performance. EFL learners from two TOEFL preparation classes participated in this research. Participants in experimental group received treatment in the form of topic familiarity. The results showed the significant effect of the prior knowledge on listening comprehension.

While the results of the mentioned studies confirmed the effectiveness of the top-down pre-listening activity, there are other studies whose findings delimit the efficiency of this type of pre-listening. Jensen and Hansen's (1995) finding on the efficiency of activating prior information on listening performance of 128 university level L2 learners revealed that it had a slight effect on the improvement of students' listening comprehension. In Herron, Cole and Linden's (1998) study, no significant difference was also found between students with receiving two types of advance organizers in two experimental groups (major-scene summary in declarative advance organizer and interrogative advance organizer). A search in the literature reveals that some studies have demonstrated the efficient role of the learners' prior knowledge on their listening comprehension; although, some other disconfirmed the efficiency of the relevant prior knowledge.

Regarding the positive role of vocabulary preparation on listening comprehension, previous studies are also incongruent. While Tsui and Fullilove (1998) and Pan (2012) indicated that bottom-up pre-listening was efficient on listening performance of the learners rather than the top-down pre-listening, Rameshianfar, Shahnazari, and Tavakoli (2015), demonstrated that vocabulary instruction as pre-listening activity did not have significant effect on listening comprehension performance of the Iranian intermediate EFL learners.

Most previous studies compared and contrasted the effects of various forms of prelistening activities on listening achievement of the learners. Berne (1995) investigated the effects of both pre-listening activities, bottom-up and top-down, on listening comprehension performance. The results revealed that vocabulary pre-teaching was less effective than other forms of listening support. Chung and Huang (1998) conducted a similar study on the effect of vocabulary instruction, advanced organizer and "combined condition" on comprehension performance of the learners. The results indicated that the combined group was more effective than vocabulary instruction and advance organizer group. However, the vocabulary group and advance organizer group were still better than the control group. Taglieber, Johnson and Yarbrough (1988), in another study, examined the effectiveness of one type of bottom-up pre-listening and two different types of top-down pre-listening activities. The researchers found that both top-down activities had significant effects on students' scores. The research of Keshvarz and Babai (2001) proved the importance of linguistic knowledge and bottom-up skills. They showed that providing relevant background knowledge didn't have any significant effect 
on listening comprehension performance of both high and low level language learners. Therefore, they questioned the overestimation of the importance of the background knowledge.

Chang and Read's (2006) research is another example of investigating the effect of two kinds of pre-listening supports on listening comprehension performance of Tai students. Their research's result showed that vocabulary instruction was the least helpful type of listening support among the other pre-activities. According to this research providing general information about the topic of the actual listening was more efficient than the other kinds of pre-listening such as repetition of input and vocabulary instruction. Chang and Read (2007) in another study examined the impact of different kinds of pre-listening on lower level language learners. Providing general information related to the topic of listening in learners' native language slightly increased the comprehension performance of the learners in the experimental group. In other words, written related information did not have any significant effect on the learners' listening comprehension performance. They came to conclusion that different types of pre-listening activities may increase the level of comprehension but to a certain degree.

Hui (2010) compared the effectiveness of pre-listening vocabulary instruction and content related support on EFL learners' listening comprehension. The results of his study revealed that providing background knowledge had significant effects on learner' listening comprehension. Farrokhi and Modarres (2012), in similar study, investigated the importance of glossary of unknown words and content support on Iranian EFL language learners' listening comprehension performance. They conducted the research across two levels of low and high proficiency. The result showed that content group had better performance than vocabulary group in high proficiency level. They suggested that in designing the pre-listening activities, the type of activity should be in accordance with the level of the learners.

An overview of the above studies on the impact of various forms of pre-listening activities shows the contradictory results. Although, there are general consensuses about the positive effects of pre-listening activities on listening comprehension achievement of the learners, there are controversial results about the effectiveness of special type of prelistening activity. Some studies, as mentioned above, confirmed the positive effects of vocabulary preparation or content related support on listening comprehension performance, some studies, on the other hand, disapproved their efficient roles. To reach solid conclusion and improve some limitations of the previous studies, this research attempted to investigate the effectiveness of both bottom-up and top-down prelistening activities on listening comprehension performance of Iranian elementary EFL learners. This study tried to determine the extent to which vocabulary preparation and content related support can help elementary EFL learners' listening comprehension performance. Based on this aim, this research attempted to find answer for the following question:

Do various pre-listening activities have any effects on Iranian elementary EFL learners' listening comprehension? 
Research hypothesis: Various pre-listening activities have no effects on the improvement of the listening comprehension performance of the Iranian elementary EFL learners.

\section{METHOD}

\section{Participants}

The participants of this study were the 90 EFL learners, studying English at a private language institute in Roudsar, Iran. Their age ranged between 15 and 18 . The participants were both male (35) and female (55). By giving a TOFEL (PBT) test and based on the Common European Framework of Reference for Languages (CEFR), 90 learners who scored between 397 and 433 were selected as elementary learners for this study. The participants were randomly assigned to two experimental and one control groups (30 for each one). In each experimental group, the subjects received one type of pre-listening as the treatment: vocabulary preparation or content related support.

Table 1

Demographic background of the participants

\begin{tabular}{ll}
\hline No. of Students & 90 EFL Learners \\
\hline Gender & 35 Male \& 55 Females \\
\hline Native Language & Persian \\
\hline Context & Iran, a Private Language Institute \\
\hline Year of Research & 2017 \\
\hline
\end{tabular}

\section{Materials}

The instruments utilized in this study included proficiency test, pretest, pre-listening activities including vocabulary preparation and content related support, listening tasks, and posttest.

\section{Proficiency test}

In order to select the 90 elementary learners, TOEFL (PBT) test was used. In this test, test takers' overall score will be between 310 and 677. In order to interpret the scores of the learners, the Common European Framework of Reference for Languages (CEFR) was used by the researcher. CEFR is an international standard used for describing the learners' language ability. It has six levels: A1 (beginner), A2 (elementary), B1(intermediate), B2 (upper-intermediate), C1 (advanced), C2 (mastery). This study focused on A2. The learners who scored between 397 and 433 were classified as elementary learners.

\section{Pretest}

In order to measure any possible pre-existing difference among the learners' listening comprehension performance in two experimental and one control groups and in order to measure the possible changes of the students' listening level after the treatment, a listening test designed by Richards (2010) was administered at the beginning of the course. 


\section{Vocabulary preparation materials}

The materials used for vocabulary preparation consisted of presenting unfamiliar words together with sentences made of these words. By conducting pilot study, unfamiliar words for teaching as pre-listening activity were chosen. The transcription of listening audios was given to 5 randomly chosen learners. The learners were asked to read the passage quickly and underline the unknown words. The researcher made a list of these unknown words to decide which words deserve pre-teaching as pre-listening activity. The final word list presented as bottom-up based pre-listening activity consisted of six to eight words for different units. As well as presenting unknown words in a word list, the learners were asked to complete the sentences with the same unknown words presented in word list for each unit. The number of the sentences was the same as the number of unknown words.

\section{Content related support}

For providing content related support as the treatment, five declarative sentences were constructed for each unit. These sentences were based on the topics of the listening passage. They were designed to explain the major events occurred in each unit. The learners were asked to read the sentences and discuss the topic that they were going to listen. The researcher had 15 minutes to lead discussion with the participants. When students were reluctant about discussion, the teacher asked some question to begin the discussion.

\section{Listening unit}

Listening materials in this experiment were chosen from "Basic Tactics for Listening" (Richards, $4^{\text {th }}$ ed, 2010). The units of Introduction and Names, Routines, Favourites, Hopes and Plans, Vacation, Health, Entertainment, the weather, describing things, describing people, Directions, and Places (Paris, Rio de Janeiro, Hong Kong, San Francisco, Sydney, Montreal) were taught.

\section{Posttest}

After the experiment, the researcher organized a listening test to measure the amount of progress. The post-test was also designed by Richards (2010). It was another version of the pretest and it had the same characteristics with the pre-test.

\section{Procedures}

This study was a quasi-experimental (the pretest posttest equivalent group) design. The results were analysed and interpreted based on the quantitative data. This study was conducted over the course of 6 weeks and 12 sessions. By giving a standardized test, TOFEL (PBT), the 90 subjects selected from the target population of Iranian EFL learners. After the random assignment of the learners to experimental and control groups (30 for each group), pretest was performed. After taking the pretest, the learners in experimental groups received their treatments. One group received bottom-up prelistening activity (vocabulary preparation) and the other group received top-down prelistening activity (content related support). In control group, listening was taught in 
traditional way, without any pre-listening activities. At the end of the course, the posttest was given to the learners. The posttest was used to measure the efficiency of two types of pre-listening activities and to see whether there were differences between these treatments and the traditional way of teaching listening.

\section{Data analysis}

SPSS (Statistical Package for Social Science) was used to perform all statistical analyses. One-way ANOVA was conducted to measure the differences of students' listening comprehension performance within and among groups (with bottom-up prelistening activity, top-down pre-listening activity and no pre-listening activity).

\section{FINDINGS}

\section{Descriptive data of the elementary learners}

Ninety subjects participated as the elementary learners in this research. 35 learners or 38.9 percent were male and 55 or 61.1 percent were elementary female participants. The descriptive data of the elementary learners including the mean scores, standard deviations, and the minimum and maximum scores of listening comprehension performance on both pretest and posttest are as follow:

Table 2

The descriptive data of the elementary learners

\begin{tabular}{|c|c|c|c|c|c|c|c|c|c|c|}
\hline \multirow[t]{2}{*}{ Variable } & \multirow{2}{*}{$\begin{array}{l}\text { Group } \\
\text { (Method) }\end{array}$} & \multirow[t]{2}{*}{ Frequency } & \multicolumn{4}{|c|}{ Pretest } & \multicolumn{4}{|c|}{ Posttest } \\
\hline & & & Mean & $\begin{array}{l}\text { Standard } \\
\text { Deviation }\end{array}$ & Min & Max & Mean & $\begin{array}{l}\text { Standard } \\
\text { Deviation }\end{array}$ & Min & Max \\
\hline \multirow{3}{*}{$\begin{array}{l}\text { Listening } \\
\text { Comprehension }\end{array}$} & Bottom-up & 30 & 21.37 & 3.882 & 13 & 27 & 28.30 & 4.364 & 16 & 35 \\
\hline & Top-Down & 30 & 21.80 & 3.044 & 14 & 27 & 27.63 & 3.746 & 20 & 35 \\
\hline & Control Group & 30 & 22.03 & 2.846 & 18 & 29 & 24.93 & 2.803 & 21 & 33 \\
\hline
\end{tabular}

\section{Inferential analysis of the data}

For investigating the research question, one-way ANOVA was carried out on the dependent variable, listening comprehension scores. There are some assumptions that must be met before ANOVA can be appropriately used. The first assumption is the normality of distribution; thus, mean and standard deviation should be the appropriate measures of central tendency. The ratio of skewness and kurtosis to its standard error can be used as a test of normality. This ratio should be in the range of -2 to +2 . In other words, one can reject normality if the ratio is less than -2 or greater than +2 . The skewness and kurtosis values of both pre-test and post-test are given in the following Table.

Table 3

The skewness and kurtosis value for the elementary learners' scores

\begin{tabular}{lllll}
\hline Indicator & Skewness & Std. Error & Kurtosis & Std. Error \\
\hline Pretest & -.304 & .254 & .158 & .503 \\
Posttest & .162 & .254 & -.334 & .503 \\
\hline
\end{tabular}


According to the above Table, the skewness and kurtosis values for both pretest and posttest are below 1, which is one index of normal dispersion of scores. Furthermore, since the ratio of skewness to its standard error is in the range of -2 to +2 , it can be concluded that the distribution of scores followed the normal distribution.

The second assumption for conducting ANOVA is homogeneity of variance. The Levene's statistics can be used to check this pre-requisite. If the significance level in Levene's test is higher than 0.05 , it can be concluded that all groups have equal variance. The results of the Levene's test for pretest and posttest scores are presented in Table 4.

Table 4

Levene's test for homogeneity of variance

\begin{tabular}{lllll}
\hline & Levene Statistic & df1 & df2 & Sig. \\
\hline Pretest & 1.435 & 2 & 87 & .244 \\
Posttest & 2.311 & 2 & 87 & .105 \\
\hline
\end{tabular}

If the significance level in the Levene's test is larger than 0.05 , then it can be said that the variances of the groups are homogenous. According to the above Table, since the significance level for pretest and posttest scores are greater than 0.05 , it can be concluded that the existing differences in sample variances can be attributed to random sampling of the population; therefore, the second assumption for running ANOVA is met.

The third assumption to be met is the type of data. In other words, the required data (dependent variable) is interval data. This assumption is also met here.

This research tried to investigate the differences of elementary EFL learners' listening comprehension performance with different types of pre-listening activities. In order to see whether there were statistically significant differences among elementary EFL learners in three groups (two experimental and one control groups), a one-way ANOVA was carried out. As Table 5 demonstrates, there were no significant differences among the mean values of these three groups.

Table 5

ANOVA results for the pretest scores of the elementary learners

\begin{tabular}{llllll}
\hline & Sum of Squares & df & Mean Square & F & Sig. \\
\hline Between Groups & 6.867 & 2 & 3.433 & .318 & .729 \\
Within Groups & 940.733 & 87 & 10.813 & & \\
Total & 947.600 & 89 & & & \\
\hline
\end{tabular}

According to the above Table, the F-value was 0.318 at $\alpha<.05$ significance level. As it is clear, it was much smaller than the critical value. Therefore; it can be concluded that the difference among three set of pre-scores were not significant and the participants in three groups were nearly equal in their listening comprehension ability at the beginning of this research. The results of ANOVA for the posttest scores are demonstrated in Table 6. 
Table 6

ANOVA results for the posttest scores of the elementary learners

\begin{tabular}{llllll}
\hline & Sum of Squares & df & Mean Square & F & Sig. \\
\hline Between Groups & 190.689 & 2 & 95.344 & 6.987 & .002 \\
Within Groups & 1187.133 & 87 & 13.645 & & \\
Total & 1377.822 & 89 & & & \\
\hline
\end{tabular}

ANOVA results, demonstrated in Table 6, indicated that the differences among three groups' posttest scores were statistically significant, $\mathrm{F}$ - value $=6.987, \mathrm{P}<.05$. The $\mathrm{F}$ ratio is 6.987 and the corresponding significance is 0.002 . Given that the Sig value is less than .05 , one was safe in accepting the differences among the mean scores of the three groups. However, the high significance of F-value merely indicated the significant differences among groups; it did not show which group was different from the other groups. Therefore, the Post-hoc Tukey tests were used to examine the differences between each pair of groups.

Table 7

Post-hoc Tukey tests for the posttest scores of the elementary learners

\begin{tabular}{lllll}
\hline (I) Group & (J) Group & Mean Difference (I-J) & Std. Error & Sig. \\
\hline Bottom-up Activity & Control Group & $3.367^{*}$ & .954 & .002 \\
Top-down Activity & Bottom-up Activity & -.667 & .954 & .765 \\
& Control Group & $2.700^{*}$ & .954 & .016 \\
Control Group & Bottom-up Activity & $-3.367^{*}$ & .954 & .002 \\
\multirow{2}{*}{ *. The mean difference is significant at the 0.05 level. } & $-2.700^{*}$ & .954 & .016 \\
\hline
\end{tabular}

In the above Table, the significance of the difference between each pair of groups with a Sig value of less than 0.05 is confirmed and proved. As can be seen, there was a meaningful difference between experimental groups (the bottom-up and top-down prelistening groups) and the control group. However, as the post-hoc Tukey tests revealed, there was no significant difference between two experimental groups with each other. The listening comprehension scores of the students receiving bottom-up pre-listening activity (vocabulary preparation) and top-down pre-listening activity (content related support) were higher than the scores of the learners who did not receive any special treatment. This means that these two pre-listening activities, vocabulary preparation and content related support, were highly effective in improving the listening comprehension performance of the elementary learners.

\section{DISCUSSION}

According to the analyses of the collected data, pre-listening activities had a significant effect on the improvement of listening comprehension performance of Iranian elementary EFL learners. The difference between the two experimental groups with the control group approved the effectiveness of pre-listening activities. While the listening comprehension performance of the learners in control group had some improvements, it was far from the level of experimental groups' improvement and failed to reach the level of significant difference. The lack of significant difference between two types of prelistening indicated that, for elementary learners, the type of pre-listening was not impressive in betterment of the learners' overall listening comprehension. In other 
words, both types had approximately the same effect on the improvement of the listening skill of the learners. Therefore, research hypothesis: pre-listening activities have no effects on the improvement of the listening comprehension performance of the Iranian elementary EFL learners, was rejected.

Many other works also investigated the effects of vocabulary instruction as pre-listening activities. While some studies confirmed the overall positive effects of this form of prelistening, some others delimited its efficiency.

Bonk (2000) in his study showed that complete comprehension is positively correlated with higher vocabulary knowledge. Chunge and Huang (1998) research's result also showed that vocabulary instruction significantly enhanced the listening performance of law intermediate learners. Farrokhi and Modarres's (2012), research results also confirmed the positive effect of unfamiliar vocabulary on the improvement of listening comprehension performance of the elementary learners.

Although the results of the above studies were the same with the present study's finding, some studies disapproved the efficiency of vocabulary preparation. For example, the results of Ehsanjou and Khodareza's (2014) and Hui's (2010) research is in sharp contrast with the findings of the present research. They found that vocabulary instruction was not an efficient means for improving listening comprehension.

The majority of the previous studies relating to the effects of the prior knowledge on listening comprehension have demonstrated the positive correlation between the learners' pre-existing knowledge and their listening comprehension achievement. The results of Hui's (2010) research approved the great impact of the activation of prior information on the listening comprehension performance of the learners. Hoang Mai's (2014) research result also revealed the positive effects of schema construction on the improvement of EFL learners' listening. The significant impact of background knowledge on learners' listening comprehension performance was also confirmed in Hoang Mai's (2014) and Bao's (2016) study. The present research's results are also in line with the mentioned prior studies. The findings of some studies (Chang and Read, 2007; Jensen \& Hansen,1995; Herron, Cole, and Linden, 1998), on the other hand, delimited the positive role of this type of pre-listening.

Generally, most studies confirmed the significant role of pre-listening. The majority of them have indicated that providing learners with pre-listening activity can help their listening comprehension performance. However, there is no general consensus about the positive effect of specific form of pre-listening activity. The findings of this research also proved that exposing EFL learners to pre-listening activities leads to better listening comprehension performance. The research's results revealed that both vocabulary preparation and content related support could enhance the listening performance of the Iranian elementary EFL learners. The essentiality of pre-listening stage is undoubted and it seems that it is worthwhile to spend much time and energy on this stage.

\section{CONCLUSION}

According to the collected data, pre-listening activities had a significant effect on the improvement of listening comprehension performance of Iranian elementary EFL 
learners. It was revealed that elementary learners benefited from both types of prelistening activities. This result confirmed the value of pre-listening instruction for EFL learners. The ANOVA results revealed that listening comprehension performance of the learners in two experimental groups has improved greatly reaching the level of significant difference with the learners in control group. Yet, there was no meaningful difference between the learners' scores in two experimental groups with vocabulary preparation and content-related support. While the listening comprehension performance of the learners in control group had some improvement, it is far from the level of experimental groups and failed to reach the level of significant difference. The lack of significant difference between the types of pre-listening indicated that, for elementary learners, the type of pre-listening was not impressive in betterment of the learners' overall listening comprehension. In other words, both types have approximately the same effect on the improvement of the listening skill of the learners. Therefore, the research hypothesis, pre-listening activities have no effects on the improvement of the listening comprehension performance of the Iranian elementary EFL learners, was rejected. Consequently, pre-listening activities like vocabulary preparation and contentrelated support which activate the relevant schema should be an integral part of teaching listening for EFL learners.

\section{REFERENCES}

An, sh. (2013). Schema theory in reading. Theory and Practice in Language Studies, $3(1), 130-134$.

Bao, X. (2016). A study on schema theory-based listening teaching mode for English majors. International Journal of English Linguistics, 6(4), 207-212.

Bartlett, F. C. (1932). Remembering: A Study in experimental and social psychology. Cambridge: Cambridge University Press.

Berne, J. E. (1995). How does varying pre-listening activities after second language listening comprehension? Hispania, 78, 316-319.

Bonk, W. J. (2000). Second language lexical knowledge and listening comprehension. International Journal of Listening, 14, 14-31.

Buck, G. (2001). Assessing listening. Cambridge, UK: Cambridge University Press.

Carrell, P.L. (1983). Some issues in Studying the role of schemata, or background knowledge in second language comprehension. Reading in a Foreign Language, 1, 8192.

Carrel, P. L., \& Eisterhold, J. C. (1983). Schema theory and ESL reading pedagogy.TESOL Quarterly, 17(4), 553-573.

Chang, A. C., \& Read J. (2007). Support for foreign language listeners: Its effectiveness and limitations. RELC, 38(3), 375- 95.

Chang, A. C-S. \& Read, J. (2006). The effects of listening support on the listening performance of EFL learners. TESOL Quarterly, 40, 375-397. 
Chiang, C. S., \&Dunkel, P. (1992). The effect of speech modification, prior knowledge, and linguistic proficiency on EFL lecture learning. TESOL Quarterly, 26(2), 345-374.

Chung, J. M. (2002). The effects of using two advance organizers with video texts for the teaching of listening in English.Foreign Language Annals, 35, 231-241.

Chung, J. M. \& Huang, S. C. (1998). The effects of three aural advance organizers for video viewing in a foreign language classroom. System, 26, 553-565.

Ehsanjou, M., \& Khodareza, M. (2014). The impact of using different forms of prelistening on Iranian EFL learners' listening comprehension. ELT Voices, 4(6), 1-10.

Eskey, D. E. (1988). Holding in the bottom: An interactive approach to the language problems of second language readers. In Carrell, Devine, \& Eskev, Interactive approach to second language reading, (pp. 93-100) Cambridge: CUP.

Fang, Xu. (2008). Listening Comprehension in EFL Teaching.Retrieved February 12, 2017, from http://www.slideshare.net/mora-deyanira/listening-comprehension-ineflteaching.

Farrokhi, F. \&Modarres, V. (2012). The effects of two pre-task activities on improvement of Iranian EFL learners' listening comprehension. Theory and Practice in Language Studies, 2(1), 144-150.

Herron, C. (1994). An investigation of the effectiveness of using an advance organizer to introduce video in the foreign language classroom. The Modern Language Journal, 78(2), 190-198.

Herron, C., Cole, H. \& Linden, p. (1998). A comparison study of student retention of foreign language video: Declarative versus interrogative advance organizer. The Modern Language Journal,82(2), 237-247.

Hoang Mai, L. (2014). Enhancing listening performance through schema construction activities. Journal of language teaching and research, 5(5), 1042-1051.

Hui, S. (2010). The effects of pre-listening vocabulary instruction and background knowledge input on non-English majors' EFL listening comprehension. Retrieved March 4, 2017 from http://www.p-papers.com/44509.html.

Jensen, C., \& Hansen, C. (1995). The effect of prior knowledge on EAP listening-test performance.Language Testing. 12 (1), 99-119.

Jia, L. (2010). How word recognition is affected by schema activation: An investigation through listening. Chinese Journal of Applied Linguistics, 33(4), 64-76.

Keshavarz, M. H., \&Babai, E. (2001). Incompatibility of schema with input in listening comprehension.Indian Journal of Applied Linguistics, 27 (1), 57-83.

Krashen, S. D. (1996). The case for narrow listening.System, 24, 97-100.

Krashen, S. D. (1985). The input hypothesis. London, UK: Longman. 
Pan, Y. C. (2012). Effects of multi-faceted lexical instruction on the TOEIC listening performance of Taiwanese EFL college students.International Journal of EnglishLinguistics, 2, 71-79.

Rameshianfar, A., Shahnazari, M. T. \&Tavakoli, M. (2015). The effect of two prelistening vocabulary and enhanced content-related supports on Iranian intermediate EFL learners' listening comprehension sub-skills. Journal of Applied Linguistics and Language Resaerch, 2(8), 284-302.

Richards, J. C. (2010). Basic tactics for listening ( $4^{\text {th }}$ ed.). Oxford University Press. Richards, J. C., \& Schmidt, R. (2010). Dictionary of language teaching \& applied linguistics. London: Pearson Edition.

Rost, M. (2002). Teaching and researching listening. London, UK: Pearson.

Rost, M. (1990). Listening in language learning. London, UK: Longman.

Sadighi, F. and Zare, S. (2002). Is listening comprehension influenced by the background knowledge of the learners? A case study of Iranian EFL learners.The linguistics Journal, Vol. 1 No. 3, pp. 110-126.

Schmidt-Rinehart, B. C. (1994). The effects of topic familiarity on second language listening comprehension.The Modern Language Journal,78(2), 179-189.

Taglieber, L. K., Johnson, L. L., \& Yarbrough, D. B. (1988). Effects of pre-reading activities on EFL reading by Brazilian college students.TESOL Quarterly, 22(3), 455472.

Tsui, A. B. M., \&Fullilove, J. (1998). Bottom-up or top-down processing as a discriminator of L2 listening performance. Applied Linguistics, 19(4), 432-451.

Underwood, M. (1989). Teaching listening. Hong Kong: Longman.

Urquhart, A. H. \& Weir, C. (1998). Reading in a Second Language: Process, Product, and Practice. Longman.

Vandergrift, L. (1999). Facilitating second language listening comprehension: acquiring successful strategies.ELT Journal, 53(3), 168-176. 